\title{
IMPLEMENTASI PRINSIP KEHATI-HATIAN DALAM MENCEGAH KREDIT PADA PT. BUANA FINANCE. DENPASAR
}

\author{
Kadek Ardy Arya Saputra, I Nyoman Putu Budiartha, Ni Made Puspasutari Ujianti \\ Fakultas Hukum Universitas Warmadewa, Denpasar-Bali, Indonesia \\ ardyaryaa99@gmail.com, budiarthaputu59@gmail.com,puspasutariujianti@gmail.com
}

\begin{abstract}
Abstrak
Indonesia merupakan negara berkembang yang perkembangan ekonominya sangat pesat. Semua jenis usaha selalu terikat dengan peraturan pemerintah. Masyarakat tidak dapat bertindak seenaknya dan harus mengikuti norma yang berlaku. Pemerintah dalam upaya pemerataan kesejahteraan rakyatnya menciptakan wadah bagi perkumpulan masyarakat untuk mengolah dana yang dimiliki atau dana pinjaman untuk membuka usaha. Penelitian ini bertujuan untuk menjelaskan prinsip kehati-hatian dalam mencegah terjadinya kredit macet dan mengungkapkan cara pencegahan dan penanggulangan kredit macet. Penelitian ini dirancang dengan menggunakan penelitian empiris dengan mengkaji, mencari dan memilah data dari berbagai buku hukum dan berdasarkan hukum sebagai dasar penelitian ini. Data yang digunakan adalah data primer dan data sekunder. Hasil penelitian mengungkapkan bahwa prinsip kehati-hatian dalam pembiayaan yang dilakukan belum cukup baik. Buana Finance memberikan pembiayaan dengan mengedepankan prinsip 5C yang meliputi Character, Capacity, Capital, Condition, dan Collateral. Cara pencegahan dan penanggulangan kredit macet dilakukan dalam dua tahap tindak lanjut yaitu tahap pertama dengan menerapkan Preventive Control of Financing yaitu dengan melakukan analisa pembiayaan, penetapan batas maksimal pemberian pembiayaan dan monitoring. Kedua dilakukan dengan Repressive Control of Financing yaitu dengan melihat penyebab dari pembiayaan bermasalah/kredit macet baik dari PT. Buana Finance cabang Denpasar.
\end{abstract}

Kata Kunci: Implementasi, Kredit, Prinsip Kehati-hatian

\begin{abstract}
Indonesia is a developing country whose economic development is very diverse. All types of businesses are always bound by government regulations. People cannot act arbitrarily and must follow the prevailing norms. The government in an effort to evenly distribute the welfare of its people creates a forum for community associations to process their funds or borrow funds to open businesses. This study aimed to explain the precautionary principle in preventing bad loans and reveal ways to prevent and overcome bad loans. This study was designed using empirical research by reviewing, searching, and sorting data from various legal books and based on the law as the basis of this research. The data used were primary data and secondary data. The results of the study revealed that the precautionary principle in financing was not good enough. Buana Finance provides financing by prioritizing the 5C principles which include Character, Capacity, Capital, Condition, and Collateral. The way to prevent and overcome bad loans is carried out in two follow-up stages, namely the first stage by implementing Preventive Control Of Financing, namely by conducting financing analysis, determining the maximum limit for providing financing, and monitoring. The second is done with Repressive Control Of Financing, namely by looking at the causes of non-performing financing / bad loans from PT. Buana Finance Denpasar branch.
\end{abstract}

Keywords: Implementation, Credit, Prudential Principle

\section{PENDAHULUAN}

Indonesia merupakan salah satu negara yang berada di Asea dan penduduknya bersebaran di berbagai pulau, tentu ini memiliki berbagai latar belakang dan keadaan tubuh yang berbedabeda. Undang-undang Dasar dan pancasila menjadi dasar Negara Indonesia. Semua warga negara wajib mengikui segala peraturan yang ada tanpa pilh bulu. Sebagai negara yang taat aturan hukum tingkah laku dan gerak-gerik manusia menjadi terbatas, boleh melakukan suatu kegiatan namun bersifat positif artinya tidak menimbulkan suatu yang dapat membahayakan 
lingkungan sekitarnya dan melukai seseorang. Tujuan diberlakukannya peraturan di Negara Indonesia untuk menciptakan kemakmuran keadilan dan kesejahteraan bagi semua orang yang berada di Indonesia tidak terkecuali wisatawan yang berkunjung juga harus mengikuti aturan yang berlaku demi menjaga keharmonisan yang ada (Riskiyono, 2015).

Masuknya wisatawan asing membuat perubahan yang signifikan bagi masyarakat mulai dari perubahan pola pikir sampai gaya hidup yang kebarat-baratan menyebabkan terjadi konflik di masyarakat yang menunjukan betapa cepatnya Indonesia mengikuti perubahan zaman. Berbicara mengenai moderenisasi dan globalisasi dewasa ini, tidak hanya terjadi di daerah metropolitan saja di Indonesia tetapi sudah masuk kedaerah pedesaan, yang memberikan dampak positif maupun negatif. Pesatnya perubahan yang terjadi di masyarakat menyebabkan banyak sekali konflik dan kesalahpahaman diantara orang atau kelompok, ego manusia yang tinggi membuat perubahan pola pikir yang ingin menguasai apapun demi keuntungan pribadi tanpa memikirkan keadaan sekitar (Jaya et al., 2021). Masyarakat kini lebih mengutamakan kepentingan pribadi dibandingkan kepentingan negara, perbuatan yang melanggar aturan norma yang berlaku terus dilakukan demi kepuasan ego menyebabkan banyaknya tindak kekerasan yang terjadi di tengah masyarakat. Tindakan tersebut tentu tidak dibenarkan, pemerintah dengan tegas menerapkan sanksi bagi seseorang yang melanggar aturan norma yang berlaku di Indonesia tanpa memandang suku, ras dan budaya baik warga kecil atau pekerja pemerintahan bisa dihadiahi hukuman bila melakukan pelanggaran norma.

Berkaitan dengan perekonomian saat ini Indonesia merupakan negara yang kaya akan kekayaan alamnya namun masih gonjang janjing dalam perekonomiannya. Pendapatan masyarakat di Indonesia sangat jauh berbeda dibanding negara-negara lainnya, pendapatan terbesar negara didapat melalui sektor pariwisata dimana menjadi daya terik tersendiri bagi para wisatawan yang hadir dan berkunjung ke Indonesia. Terdiri dari berbagai pulau yang masyarakatnya berjumlah jutaan jiwa ditiap tiap wilayah membuat angka kemiskinan kian meningkat. PT. Buana Finance hadir dengan solusi memberikan pinjaman dengan bunga rendah dan angsuran yang terjangkau dengan jaminan yang diberikan sebagai pegangan pihak finance guna mencegah terjadinya wanprestasi dikemudian hari. Semakin besar pinjaman semakin besar juga jaminan yang harus disediakan oleh masyarakat ditambah pengecekan kemampuan terlebih dahulu oleh pihak finance agar memastikan seorang yang meminjam dan bisa membayar setiap bulannya. Setelah dilakukan pengecekan maka dana pinjaman akan ditentukan oleh direktur yang memberikan pinjaman di Buana Finance apakah layak tidaknya seorang diberi pinjaman. Tidak semua orang dapat meminjam terkecuali sudah pernah melakukan pinjaman sebelumnya karena telah memiliki data pinjman yang bersih dan Buana Finance mengutamakan pihak yang meminjam hanya untuk keperluan usaha bukan untuk keperluan yang lain yang nantinya beresiko menyebabkan terjadinya wanprestasi.

PT. Buana Finance juga memiliki fungsi yang sama seperti lembaga perbankan yaitu untuk menghimpun dana dan menyalurkan kembali kepada anggota. Sebagai organ social maka koperasi perlu mengutamakan dimensi kehidupan social yaitu peningkatan kualitas kehidupan masyarakat. Lembaga keuangan dalam pemberian simpan pinjam menekankan pada bidang permodalan untuk mewujudkan tujuan dari koperasi tersebut maka masyarakat wajib bekerjasama karena kerjasama ini akan menguntungkan kedua belah pihak. Kerja sama tersebut dilakukan dengan meminjam modal kepada masyarakat yang membutuhkannya. Dalam memberikan pinjaman harus dilakukan dengan perjanjian kredit yang disepakati oleh peminjam. Dengan adanya perjanjian kredit ini di satu pihak, peminjam memperoleh kredit tersebut dengan harapan agar usaha yang dilakukan dapat berkembang dan dapat memenuhi kebutuhannya yang lain (Asmawati, 2015). Sedangkan pada pihak Buana Finance memperoleh keuntungan dari pemungutan bunga kredit. Disamping itu untuk menjamin pelunasan utangnya dalam perjanjian kredit tersebut, pihak peminjam diharuskan memberikan jaminan kepada pihak Buana Finance sebagai pelunasan utang apabila si peminjam suatu saat tidak bias melunasi pinjamannya. Jadi sudah seharusnya apabila masingmasing pihak dalam suatu perjanjian yang telah diadakan harus melaksanakan isi perjanjian yang telah disepakati. Setiap pihak yang melakukan perjanjian harus memiliki etikad baik 
yaitu mematuhi setiap isi perjanjian dan tidak melakukan wanprestasi yang berakibat batalnya suatu perjanjian

Dalam perekonomian Indonesia, Negara sebagai wadah dari rakyat untuk meningkatkan kesejahteraan rakyat. Di era sekarang uang menjadi yang utama bisa dikatakan dengan uang seseorang dapat memiliki apapun. Percaya tidak percaya Indonesia dapat bertahan karena pajak yang dihasilkan dari setiap penghasilan masyarakat serta meningkatkan perekonomian dari masyarakat dan nasional. Semakin padatnya penduduk maka semakin banyak orang yang memerlukan uang demi bertahan hidup. Koperasi merupakan solusi pemerintah dalam menekan angka kemiskinan namun demi bisa mendapatkan modal usaha harus mengisi formulir serta mengikuti syarat dan ketentuan. Lembaga keuangan merupakan alternatif terbaik saat ini bagi masyarakat yang ingin mengembangkan usaha demi meningkatkan sumber pendapatnya namun demi mendapatkan pinjaman diperlukan beberapa syarat seperti jaminan yang setara dengan modal yang ingin dipinjam serta ketentuan bunga yang berlaku disetiap koperasi berbeda-beda tergantung besar dana pinjaman (Rochaida, 2016). Sasaran lembaga ialah masyarakat dengan ekonomi menengah kebawah, biasanya jika ada masyarakat ekonomi menengah keatas akan dipertimbangkan terlebih dahulu baru diputuskan apakah mendapat pinjaman dana atau tidak namun bagi masyarakat ekonomi menengah kebawah akan dipermudah dalam proses peminjaman dana.

Permasalahan yang timbul kemudian adalah di satu pihak, apabila setelah melakukan pelelangan atau penjualan benda jaminan milik debitur bersama-sama dengan pihak Buana Finance ternyata jaminan yang dibayarkan oleh debitur masih bernilai kurang atau jaminan tersebut tidak dapat mencukupi pelunasan utang kreditur. Sedangkan di pihak lain harus menuntut pemenuhan prestasi berupa pelunasan utang dari pihak debitur yang juga merupakan anggota koperasi. Terkait dengan masalah tidak mencukupinya hasil eksekusi benda jaminan kredit untuk pelunasan utang debitur kepada pihak Buana Finance, maka berdasarkan pemaparan latar belakang masalah dapat diteliti lebih jauh mengenai penyelesaian yang dilakukan oleh pihak koperasi dalam menuntut pelunasan utang debitur jika eksekusi benda jaminan kredit milik debitur ternyata tidak mencukupi untuk pelunasan utangnya.

Pada setiap perjanjian masing-masing pihak diwajibkan untuk memenuhi apa yang menjadi isi dari perjanjian atau dapat dikatakan bahwa masing-masing pihak wajib untuk memenuhi prestasinya, perjanjian kredit menimbulkan hak dan kewajiban bagi para pihak yang membuat perjanjian kredit (Respationo, 2013). Sehingga dalam pelaksanaannya perjanjian kredit juga dapat menimbulkan akibat hukum bagi pihak kreditur dan debitur yang menyepakatinya (Kambey, 2017). Selanjutnay Perbuatan seseorang yang melakukan sesuatu yang merugikan orang lain misalnya penyiksaan, pelecehan, pembunuhan sampai mengakibatkan kematian diharuskan mempertanggungjawabkan perbuatannya karena siapa yang menanam dia yang memetik (Manggala et al., 2021). Dari beberapa temuan penelitian terdahulu, mak peneliti melakukan penelitian yang berfokus pana kajian tentang prinsip kehati-hatian dalam mencegah terjadinya kredit macet serta mengungkapkan cara pencegahan dan mengatasi kredit macet.

\section{METODE PENELITIAN}

Penelitian didesain dengan penelitian empiris. Penelitian empiris dilakukan dengan mencari data langsung kelapangan dan melalui buku ilmu hukun dan menghubungkan dengan permasalahan yang diangkat kemudian mengkaitkan dengan Perundang-undangan yang berlaku saat ini (Waluyo, 1996). Peneliti mengkaitkan dengan peraturan yang berlaku dan tidak menyimpang dari Undang-undang dasar. Pendekatan penelitian dengan cara mengkaji, mencari dan memilah data dari berbagai bukum hukum dan berpatokan pada Undang-undang sebagai dasar. Data yang digunakan adalah data primer dan sekunder yaitu data yang berasal dari beberapa UU yang terkait berbagai referensi buku hukum yang terkait dan menghasilkan skripsi yang tidak melenceng dari hukum positif (Ahmad, 2008). Selanjutnya seteleh semua data penelitian terkumpul maka datavtersebut dianalisis melalui analisis kualitatif deskriptif. 


\section{HASIL DAN PEMBAHASAN}

\section{Penerapan Prinsip Kehati-Hatian demi Mencegah Terjadinya Kredit Macet}

Sudah diketahui banyak orang bila seseorang ingin meminjam modal usaha harus ada jaminan yang harga jualnya sesuai modal yang dipinjam, kegiatan ini dilakukan oleh lembaga-lembaga keuangan kepada nasabah atau anggota mereka golongan ekonomi menengah kebawah. Tidak semudah yang terlihat sebelum melakukan pinjaman harus mengisi formulir serta mengajak salah satu sanak saudara sebagai saksi telah dilakukannya perjanjian pinjam dana antara nasabah dengan pihak lembaga keuangan. PT. Buana Finance cabang denpasar dalam melakukan suatu perjanjian para pihak harus sepakat mengenai isi perjanjian, para pihak yang bersangkutan secara bersama-sama terlebih dahulu mendiskusikan isi perjanjian agar tidak ada pihak tidak menyukai perjanjian.

Tujuan perjanjian sendiri mempermudah para pihak untuk saling mendapatkan hak tanpa melupakan kewajiban, hal itu selalu ada diperjanjian. Para pihak harus memahami dasar perjanjian seperti arti kata sepakat, kewajiban dulu lalu mendapatkan hak, sanksi bagi pihak yang terbukti melakukan wanprestasi serta harus berisi kuasa hukum, nantinya kuasa hukum yang mengarahkan para pihak menyelesaikan perkara akibat wanprestasi salah satu pihak. Isi perjanjian kredit tersebut dari pihak debitur sudah harus mengerti akan isi perjanjian kredit tersebut, karena dalam perjanjian tersebut, debitur yang tidak melunasi utangnya sudah menyadari bahwa barang berharganya, baik barang yang bergerak maupun yang tidak bergerak, baik yang sudah ada maupun yang akan ada dikemudian hari, akan menjadi jaminan dan bank akan menyita benda atau harta kekayaan milik debitur tersebut untuk menutupi kekurangan pelunasan utang debitur. Sesuai perjanjian kredit tersebut, maka pihak bank dapat menyita benda-benda atau harta kekayaan milik debitur melalui penetapan pengadilan. Kemudian diajukan permohonan kepada kantor Lelang Negara untuk mengambil harta kekayaan debitur yang lain untuk melunasi hutang-hutang debitur.

Sebuah perjanjian yang memasukan kuasa hukum untuk mengamankan aset masing-masing jika suatu hari terjadi wanprestasi tugas kuasa hukum memberi pilihan penyelesaian sengketa mulai dari memakan waktu dan tenaga yang banyak sampai penyelesaian alternatif atau yang lagi buming belakangan tahun ini. Menurut Atmadja \& Budiartha, (2018) Dua cara penyelesian sengketa yaitu litigasi dan non litigasi, keduanya memiliki aturan ketentuan berbeda. Mulai dari jalur litigasi, setiap pihak merasa dirugikan mengajukan gugatan melalui pengadilan, mempercayakan putusan dan aturan main oleh hakim ketua. Biasanya setiap orang yang melakukan litigasi sudah tidak menemukan titik terang dari negosiasi dari penyelesaian secara non litigasi. Aturan waktu serta pemanggilan beberapa orang yang menjadi saksi membuat proses litigasi berjalan lambat, butuh waktu beberapa bulan menyelesaikan tuntutan yang diajukan. Memilih jalur non litigasi atau jalur singkat penyelesaian masalah sangat tepat karena proses tidak membutuhkan waktu lama seperti jalur litigasi (Hermansyah, 2014). Cara penyelesaiannya cukup mudah yaitu kedua belah pihak melakukan negosiasi atau mencari jalan tengah agar perjanjian kembali berlanjut dan selesai sesuai isi perjanjian yang sudah disepakati bersama. Secara meluas penyelesaian sengketa non litigasi dapat dilakukan efisien waktu dan dana tidak begitu besar yaitu :

1. Penjadwalan kembali (reschduling), yaitu proses yang dilakukan antara kedua belah pihak dengan cara mengganti cara pembiayaan bisa dilakukan semisal penggantian jangka waktu pembayaran dan meminta tempo semua dilakukan demi melancarkan pembayaran yang sebelumnya tertunggak agar sesuai dengan keinginan kedua belah pihak yang melakukan perjanjian dan lancarnya kegiatan di finance.

2. Persyaratan kembali (reconditioning), yaitu proses pengkajian ulang pembayaran yang sudah dilakukan mencari letak kejanggalan yang menyebabkan penunggakan pembayaran ditambah mengetahui kemampuan peminjam dana dalam membayar angsuran guna memungkinkan dilanjutkannya pembayaran sampai lunasnya angsuran sesuai dengan perjanjian yang dilakukan kedua belah pihak.

3. Penataan kembali (restructuring), yaitu proses memulai lagi dari awal seperti saat melakukan pinjaman yang ada dikurangi dengan pembayaran yang telah dilakukan sebelumnya biasanya penataan kembali dilakukan oleh pihak finance dengan perusahaan bukan perorangan jadi jelas dana yang didapat sehingga memungkinkan dibuatnya perjanjian ulang dengan kesepakatan yang berbeda. 
Setiap permasalah pasti ada jalan tengah demi kebaikan kedua pihak, kebanyakan pihak yang mengambil jalur non litigasi permasalahannya selesai dengan waktu singkat namun tidak semua penyelesaian secara non litigasi menemukan titik tengah. Perselisihan antara pihak yang bersitegang bahwasanya pihaknya benar membuat non litigasi tidak dapat dilakukan maka beralih ke jalur litigasi (Fuady, 2014). Persetujuan hakim diperlukan sebelum memulai sidang perkara wanprestasi, menunggu selama seminggu minimal dilanjutkan pemanggilan pihak - pihak terkait dalam perjanjian seperti para pihak, saksi, pegawai koperasi yang menyaksikan perjanjian di buat. Akhir sidang memutus salah satu pihak keluar sebagai pemenang, jika pihak nasabah menang akan menadapatkan ganti rugi dari pihak koperasi, jika pihak koperasi menang dalam persidangan maka berhak melelang jaminan milik nasabah sesuai isi perjanjian serta berhak meminta ganti rugi apabila hasil jual barang jaminan nasabah tidak mencukupi hutang nasabah.

\section{Penyelesaian Kredit Macet pada PT. Buana Finance. TBK}

Terjadinya kesalahan dalam memberikan pinjaman namun tidak memperhitungkan nilai tukar suatu jaminan membuat bank menjadi rugi dan susah menuntut pihak debitur karena kesalahan fatal ada pada bank bukan berarti pihak debitur bisa lepas begitu saja sebagai masyarkat yang taat aturan pihak debitur juga wajib melunasi sisa pembayaran atau wanprestasi dari perjanjian yang disepakati antara pihak bank dan pihak debitur yang bersifat mengikat bagi kedua pihak yang bersangkutan. Tidak terjalin komunikasi yang baik antar pihak bank baik antara atasan dengan staf atau sebaliknya terkait jaminan pinjaman yang diajukan masyarakat terjadinya penurunan nilai saham yang dimiliki bank, bagaimana tidak seseorang dapat dengan gampang meminjam modal untuk urusan tertentu dengan jumlah berapapun namun jaminan yang digunakan tidak memiliki nilai sama dengan dana yang dipinjam.

Pemerintah sebagai pengamat keuangan negara memberitahukan kepada pihak bank secara berulang -ulang agar teliti dalam melakukan transaksi terutama dalam bidang keuangan karena sedikit melakukan kesalahan akan berpengaruh besar kepada perusahaan begitu sebaliknya semakin efisien dalam melakukan suatu pekerjaan hasil yang diperoleh akan dinikmani seluruh penghuni perusahaan tanpa kecuali. PT. Bank Buana Finance cabang denpasar menjadi contoh kesalah kecil yang dibuat tanpa disadari secara terus menerus melakukan pemberian pinjaman tanpa memikirkan nilai dari suatu jaminan yang digunakan debitur membuat kewalahan pihak buana finance dalam upaya mengembalikan dana yang dipinjam debitur tanpa terjadi kerugian. Setelah dilakukannya prosedur penanganan pembiayaan bermasalah oleh pihak PT. Buana Finance cabang Denpasar. Pembiayaan bermasalah atau kredit macet tersebut dapat di selesaikan. Dari hasil wawancara yang dilakukan peneliti, dapat di ketahui bahwa penerpan prinsip kehati-hatian dalam mencegah dan mengatasi pembiayan bermasalah pada PT. Buana Finance telah dilakukan dengan baik. Yaitu melakukan identifikasi masalah yang dihadapi oleh nasabah dengan melakukan tindakan Recheduling, Reconditioning, Restructuring dan melakukan menyita barang jaminan.

\section{SIMPULAN DAN SARAN}

\section{Simpulan}

Dari hasil analisis data, diketahui bahwa PT. Buana Finance cabang Denpasar dalam menerapan prinsip kehati-hatian dalam pembiayaan yang telah dilakukan belum cukup baik, pihak Buana Finance memberikan pembiayaan dengan menekankan prinsip 5C yang meliputi Character, Capacity, Capital, Condition dan Colleteral. Namun lebih mengutamkan pada aspek analisis Character (karakter), Capacity (kemampuan), dan Colleteral (jaminan). Hal yang paling penting dalam pemberian pembiayaan kepada nasabah atau calon nasabah adalah colleteral (jaminan). prinsip 5C belum sepenuhnya dapat mencegah pembiayaan bermasalah karena kurang berhati-hatinya Account office (AO) dalam menganalisis pembiayaan. Mencegah kredit yang macet dengan menerapkan Preventive Control Of Financing yaitu dengan cara melakukan analis pembiayaan, menetapkan batas maksimum pemberian pembiayaan dan melakukan pemantauan, kedua dengan Repressive Control Of Financing, yakni dengan melihat penyebab pembiayaan bermasalah/kredit macet baik dari intrent PT. Buana Finance cabang Denpasar.

\section{Saran}


Dari simpulan penelitian di atas, adapun saran dari peneliti yaitu diharapkan kepada PT. Buana Finance cabang Denpasar lebih teliti saat melakukan serangkaian prosedur terhadap nasabah terkait prinsip kehati-hatian yang diterapkan oleh PBRS untuk megatasi kredit macet. Account Officer (AO) lebih memperhatikan perkembangan kondisi nasabah pembiayaan, baik dari lingkungan pribadi maupun lingkungan usahanya dengan memonitoring atau melakukan pembinaan Pihak PT. Buana Finance cabang Denpasar bisa lebih tegas terhadap nasabahnasabah yang bermasalah. PT. Buana Finance cabang Denpasar perlu menyediakan SDM yang memadai untuk menunjang kegiatan operasionalnya agar dapat melakukan program pendampingan insentif terhadap calon nasabah yang memperoleh pembiayaan sehingga dapat memperkecil risiko yang timbul dari pembiayaan kredit macet tersebut.

\section{DAFTAR PUSTAKA}

Ahmad, B. (2008). Metode Penelitian Hukum. Pustakasetia.

Asmawati. (2015). Analisis Yuridis Penyalahgunaan Kartu Kredit Terhadap Para Pihak dalam Perjanjian Jualbeli. Jurnal Ilmu Hukum, 46-64.

Atmadja, I. D. G., \& Budiartha, I. N. P. (2018). Teori-Teori Hukum. Setara Pres. Malang.

Fuady, M. (2014). Konsep Hukum Perdata PT Raja Grafindo Persada Jakarta. Jakarta: Raja Grafindo Persada.

Hermansyah. (2014). Kepastian Hukum dalam Penyelesaian Kredit Bermasalah. Kencana.

Jaya, I. W. M., Dewi, A. . S. L., \& Widyan, I. M. M. (2021). Akibat Jukum Jual Beli Organ Tubuh Manusia dalam Hukum Positif di Indonesia. Konstruksi Hukum, 2(3), 661-666.

Kambey, E. E. (2017). Analisis tentang Perjanjian Perkawinan Ditinjau dari Putusan Mahkamah Konstitusi Nomor 69/PUU-XIII/2015. Lex Privatum, 5(9), 1-14.

Manggala, I. G. F., Dewi, A. A. S. L., \& Suryani, L. P. (2021). Tinjauan Yuridis Tindak Pidana Kebiri dalam Perspektif Hak Asasi Manusia. Jurnal Konstruksi Hukum, 2(1), 4651.

Respationo, H. M. S. (2013). Pemilihan Kepala Daerah Demokrasi Electoral. Jurnal Magister Hukum, 42(3), 355-361.

Riskiyono, J. (2015). Partisipasi Masyarakat dalam Pembentukan Perundang-undangan untuk Mewujudkan Kesejahteraan. Aspirasi, 6(2), 160-176.

Rochaida, E. (2016). Dampak Pertumbuhan Penduduk Terhadap Pertumbuhan. Forum Ekonomi, 18(1), 14-24.

Waluyo, B. (1996). Penelitian Hukum Praktek. Sinar Grafika. 